\title{
ANALISIS STRATEGI PEMASARAN BAGI PELAKU USAHA MIKRO DI ERA REVOLUSI INDUSTRI 4.0
}

\author{
Kamaludin \\ Akademi Maritim Cirebon \\ kamaludin.abahrizka@gmail.com
}

\begin{abstract}
ABSTRAK
Penggunaan teknologi digitalisasi memiliki nilai positif dalam kegiatan usaha yaitu interaksi antara penjual dan pembeli dalam transaksi kegiatan usaha tanpa harus berinteraksi langsung atau tanpa bertatap muka, biaya yang digunakan relatif murah, semakin tidak terasanya faktor jarak, serta ketersediaan selama 24 jam secara penuh. Kurangnya pemahaman terhadap strategi pemasaran serta terhadap peluang pengembangan kegiatan usaha melalui sistem teknologi digitalisasi merupakan permasalahan yang akan dikaji dalam penelitian ini.

Penelitian ini bertujuan untuk memperoleh gambaran terhadap strategi pemasaran yang dilakukan oleh pelaku usaha mikro serta memperoleh kajian mendalam terhadap konsep strategi pemasaran yang relevan bagi pelaku usaha mikro di era Revolusi Industri 4.0 dan mengembangkan kegiatan usaha melalui sistem teknologi digitalisasi. Penelitian ini menggunakan pendekatan kualitatif dengan fokus penelitian yaitu menganalisa strategi pemasaran yang tepat bagi pelaku usaha mikro di era Revolusi Industri 4.0 dalam rangka mengembangkan usahanya. Teknik pengumpulan data yang digunakan dalam penelitian ini adalah teknik observasi, teknik wawancara, dan teknik dokumentasi.

Penelitian ini menghasilkan bahwa terdapat empat komponen utama dalam penerapan strategi pemasaran yaitu spesifikasi produk dengan merek, analisis penetapan harga, distribusi yang digunakan, dan mekanisme mengenalkan produk dengan melakukan edukasi terhadap konsumen. Keberlangsungan sebuah kegiatan usaha tergantung dari kualitas yang dihasilkan. Tanpa kualitas yang baik, modal yang sudah dikeluarkan akan sulit mencapai tingkat pengembalian produksi maupun tingkat pengembalian investasi. Standar kualitas ini merupakan tolak ukur yang diyakini dan dilaksanakan dengan komitmen sebagai sebuah filosofi dalam berbisnis bagi pelaku usaha mikro. Standar kualitas ini harus menjiwai strategi marketing dari mulai internal marketing, eksternal marketing maupun interaktive marketing
\end{abstract}

Kata kunci : Pelaku usaha mikro, revolusi industri 4.0, strategi pemasaran

\section{ABSTRACT}

The use of digitalization technology has a positive value in business activities namely the interaction between the seller and the buyer in the transaction of business activities without having to interact directly or without face-to-face, the cost used relatively cheaply, the less noticeable the distance factor, and the availability for 24 hours in full. Lack of understanding of marketing strategies as well as business activity development opportunities through digitalization technology systems is an issue that will be reviewed in this study. 
This research aims to obtain an overview of marketing strategies carried out by micro-entrepreneurs as well as obtain an in-depth study of the concept of marketing strategies relevant to micro-enterprises in the era of Industrial Revolution 4.0 and develop business activities through digitalization technology systems. This research uses a qualitative approach with a research focus that is analyzing the right marketing strategies for micro-entrepreneurs in the era of the Industrial Revolution 4.0 to grow their business. The data collection techniques used in this study are observation techniques, interview techniques, and documentation techniques.

This research hypothesizes that there are four main components in the implementation of marketing strategies, namely product specifications by brand, pricing analysis, the distribution used, and mechanisms of introducing products by educating consumers. The sustainability of business activity depends on the quality produced. Without good quality, the capital already issued will be difficult to achieve the level of return on production as well as the rate of return on investment. This quality standard is a benchmark that is believed and implemented with a commitment as a philosophy in doing business for micro-businesses. This quality standard should animate marketing strategies ranging from internal marketing, external marketing, and interactive marketing.

Keywords: Marketing strategy, micro-business struggle, industrial revolution 4.0

\section{A. PENDAHULUAN}

Dalam perkembangan ekonomi dewasa ini, informasi yang dibutuhkan dalam pengembangan kegiatan usaha dapat di akses dengan mudah melalui pemanfaatan sistem teknologi digitalisasi yang telah tersedia saat ini sebagai sebuah simbol dalam penerapan Revolusi Industri 4.0 . Menurut Angela Merkel, revolusi industri 4.0 adalah transformasi komprehensif dari keseluruhan aspek produksi di industri melalui penggabungan teknologi digital dan internet dengan industri konvensional (Hoedy Prasetyo dan Wahtudi Sutopo, 2018 : 19). Sedangkan menurut Schlechtendahl dkk, revolusi industri 4.0 adalah sebuah lingkungan industri dimana seluruh entitasnya selalu terhubung dan mampu berbagi informasi satu dengan yang lain (Hoedy Prasetyo dan Wahtudi Sutopo, 2018 : 19). Dalam penggunaan teknologi digitalisasi, perlu pemahaman dasar yang dibutuhkan dalam penggunaanya. Teknologi digitalisasi merupakan salah satu bentuk penerapan pelayanan self service yang berarti bahwa ketercapaian kepuasan pengguna tergantung dari kemampuan pengguna itu sendiri atau dengan kata lain pengguna berkontribusi terhadap kepuasan layanan yang akan diperoleh bagi kepuasan dirinya sendiri. Pemahaman dasar/kompetensi dalam penggunaan teknologi 
digitalisasi bukan sesuatu yang rumit, hanya perlu membiasakan diri bagi penggunaanya dan mendapatkan bimbingan dari yang sudah memiliki pemahaman dalam penggunaan teknologi digitalisasi tersebut.

Penggunaan teknologi digitalisasi memiliki nilai positif dalam kegiatan usaha, di antaranya yaitu interaksi antara penjual dan pembeli dalam transaksi kegiatan usaha tanpa harus berinteraksi langsung atau tanpa bertatap muka, biaya yang digunakan relatif murah dengan hanya tersedianya akses internet, semakin tidak terasanya faktor jarak, serta ketersediaan selama 24 jam secara penuh. Namun di samping manfaat tersebut, penggunaan teknologi memiliki nilai negatif yaitu transaksi menggunakan teknologi digitalisasi rentan akan penipuan baik terhadap barang yang dijual maupun transaksi pembayaran yang dilakukan.

Pemasaran menggunakan media digital sangat penting untuk di aplikasikan dalam dunia bisnis saat ini. Sebuah produk baru dapat diperkenalkan kepada konsumen dengan mudah melalui media digital yang dapat di akses oleh seluruh segmen konsumen. Selain itu juga, kesempatan untuk dapat memperoleh minat dari pembeli potensial dapat melalui tampilan-tampilan promosi produk melalui gambar yang di tampilkan dengan proses edit yang baik secara digital sehingga dapat lebih menarik dan meyakinkan sehingga kesempatan untuk produk terjual lebih besar. Pemasaran melalui media digital memberikan banyak pilihan bagi konsumen, sehingga perlu dipahami dengan baik oleh pelaku usaha mikro bahwa media digital menjadi pilihan pertama konsumen dalam memperoleh referensi tentang sebuah produk yang akan dibeli atau dikonsumsi (Muhtad Fadly dan Agus Wantoro, 2020), (Yuga Pratama, 2019). Peluang ini seharusnya dapat dimanfaatkan dengan baik oleh pelaku usaha mikro dalam rangka meningkatkan jumlah penjualan produknya.

Berkaitan dengan hal itu, persaingan usaha di era Revolusi Industri 4.0 saat ini sangat ketat dikarenakan manusia di era ini bukan hanya bersaing dengan sesama manusia tetapi juga bersaing dengan mesin disertai dengan sistem teknologi digitalisasi. Di era ini manusia dituntut untuk dapat mempersiapkan dirinya untuk memiliki kompetensi yang handal sebagai pencipta sistem maupun tenaga ahli dalam pengoperasian sistem teknologi digitalisasi. Perlu disadari bahwa pelaku usaha mikro harus mampu berkembang sesuai dengan perkembangan zaman/era 
saat ini agar kegiatan usahanya tetap dapat beroperasional melalui beragam inovasi strategi pemasaran yang dilakukan melalui pemanfaatan sistem teknologi digitalisasi.

Data Badan Pusat Statistik (BPS) mengungkapkan kini sudah ada 59,2 juta UMKM dan sekitar 58 juta lebih diantaranya pelaku usaha mikro dan dari 59,2 juta UMKM yang ada di Indonesia hanya 3,79 juta telah mengadopsi penggunaan teknologi digital.. Menyikapi hal itu, pelaku usaha mikro saat ini hanya menggunakan strategi pemasaran konvensional dengan menggunakan metode direct marketing. Direct marketing/Pemasaran secara langsung merupakan hubungan secara langsung dan cermat yang ditargetkan kepada konsumen individu untuk mendapatkan tanggapan langsung dari keduanya dan dapat menumbuhkan hubungan baik dengan pelanggan (Kotler \& Armstrong, 2014 : 429). Berkaitan dengan hal ini, strategi pemasaran langsung merupakan penggunaan saluran langsung konsumen untuk menjangkau dan mengirimkan barang dan jasa kepada pelanggan tanpa menggunakan perantara pemasaran (Enda Aulia Akbar Ginting Suka dan Suwardi Lubis, 2019). Hal ini dikarenakan pelaku usaha mikro memiliki pemahaman yang sangat sederhana terhadap kegiatan usaha yang dijalankan, orientasi pokok pemikiran pelaku usaha mikro hanya menyiapkan kegiatan usahanya hanya untuk hari ini. Hari ini disiapkan dan bagaimana hari ini harus menjual. Konsep pemikiran ini mengindikasikan bahwa pelaku usaha mikro menyediakan bahan baku sebatas hanya untuk kebutuhan hari ini, kemudian diolah menjadi barang jadi untuk di jual hari ini, jumlah setiap barang yang disiapkan untuk dijual jumlahnya tetap untuk setiap harinya yang berakibat jumlah pendapatan yang diperoleh jumlahnya juga tetap untuk setiap harinya. Kurangnya pemahaman terhadap strategi pemasaran serta kurangnya pemahaman terhadap peluang pengembangan kegiatan usaha melalui sistem teknologi digitalisasi merupakan permasalahan yang akan dikaji dalam penelitian ini.

Penelitian ini bertujuan untuk memperoleh gambaran terhadap strategi pemasaran yang dilakukan oleh pelaku usaha mikro serta memperoleh kajian mendalam terhadap konsep strategi pemasaran yang relevan bagi pelaku usaha mikro di era Revolusi Industri 4.0 dan megembangkan kegiatan usaha bagi pelaku 
usaha melalui sistem teknologi digitalisasi. Dalam memecahkan permasalahan yang ada, pemanfaatan media sosial menjadi salah satu solusi dalam pengembangan kegiatan usaha bagi pelaku usaha mikro sebagai sarana media promosi bagi produk yang akan dijual.

\section{B. METODE PENELITIAN}

Berdasarkan tujuan penelitian serta permasalahan yang akan diteliti, penelitian ini menggunakan pendekatan kualitatif. Penelitian ini dilaksanakan selama 3 bulan, yaitu pada bulan januari sampai dengan maret 2020, dengan tempat penelitian di Kabupaten Brebes Provinsi Jawa Tengah. Fokus penelitian yang dikaji dalam penelitian ini adalah menganalisa strategi pemasaran yang tepat bagi pelaku usaha mikro di era Revolusi Industri 4.0 dalam rangka mengembangkan usahanya.

Berdasarkan sumber datanya, data yang diperoleh dalam penelitian ini dapat dikelompokkan menjadi dua yaitu data primer dan sekunder. Data primer diperoleh dari observasi atau pengamatan langsung di lapangan dan wawancara dengan responden/informan sedangkan data sekunder adalah data yang bersumber pada dokumen yang berupa foto, catatan, rekaman, gambar dan lain-lain. Teknik pengambilan informan yang digunakan dalam penelitian ini adalah teknik Purposive Sampling (sampling bertujuan), Purposive sampling adalah dimana peneliti cenderung memilih informan yang dianggap tahu mengetahui informasi dan masalahnya secara mendalam dan dapat dipercaya untuk menjadi sumber data yang mantap (HB. Sutopo, 2002: 56). Informan dalam penelitian ini adalah pelaku usaha mikro beserta konsumennya yang ada kabupaten Brebes sejumlah 30 orang.

Teknik pengumpulan data yang digunakan dalam penelitian ini yaitu teknik observasi, teknik wawancara, dan teknik dokumentasi. Dalam penelitian kualitatif yang menjadi instrumen atau alat penelitian adalah peneliti itu sendiri. Peneliti kualitatif sebagai human instrument, berfungsi menetapkan fokus penelitian, memilih informan sebagai sumber data, melakukan pengumpulan data, menilai kualitas data, analisis data, menafsirkan data dan membuat kesimpulan atas semuanya (Sugiyono, $2005: 59$ ).

Teknik analisis data dengan menggunakan model analisis interaktif (Interactive Model of Analisys) yaitu 1)Pengumpulan data, dimana peneliti 
mengumpulkan data dari berbagai sumber antara lain buku-buku yang relevan, informasi dan keterangan berupa pendapat, tanggapan, serta pandangan yang diperoleh dari informan. 2) Reduksi data, dimana peneliti menentukan beberapa informan yang paling sesuai dengan apa yang diperlukan oleh peneliti, sehingga data yang akan diperoleh menjadi lebih akurat. 3) Penyajian data, dimana peneliti menjabarkan informasi yang telah direduksi dalam bentuk narasi kalimat, gambar/skema, maupun tabel yang memungkinkan kesimpulan penelitian dapat dilakukan 4) Penarikan kesimpulan, dimana peneliti menarik kesimpulan dari penelitian yang dilakukan.

\section{HASIL DAN PEMBAHASAN}

Strategi pemasaran adalah suatu skema yang digunakan dalam menentukan arah kebijakan dalam pengelolaan produk, harga, tempat, dan promosi dalam mencapai suatu target penjualan dan pasar tertentu. Terdapat 4 komponen utama dalam penerapan strategi pemasaran yaitu spesifikasi produk dengan merek, analisis penetapan harga, distribusi yang digunakan, dan mekanisme mengenalkan produk dengan melakukan edukasi terhadap konsumen. Strategi pemasaran adalah logika pemasaran dimana unit bisnis berharap untuk menciptakan nilai dan memperoleh keuntungan dari hubungannya dengan konsumen (Kotler and Amstrong, 2008 : 45). Selain itu, strategi pemasaran adalah keseluruhan program perusahaan dalam menentukan target pasar dan memuaskan konsumen dengan membangun kombinasi elemen dari Marketing Mix yang terdiri dari produk, tempat, promosi dan harga (Kurtz, $2008: 42$ ).

komponen yang pertama yaitu spesifikasi produk dengan merek tertentu, hal ini penting karena suatu produk harus memiliki identitas sebagai pembeda terhadap produk yang dihasilkan oleh pesaing. Dengan memiliki merek/nama produk yang dihasilkan, pelaku usaha mikro akan memiliki identitas terhadap produk ataupun bisnis yang dijalankan. Hal ini akan menimbulkan ekuitas terhadap merek, dimana merek akan tertanam kuat dalam benak dan ingatan konsumen. Disisi lain, kita ketahui bahwa dalam bisnis yang dijalankan pelaku usaha mikro yang satu dengan yang lain senantiasa terdapat produk yang essensinya adalah sama, baik dari bahan baku maupun pengolahanya. Contohnya antara penjual fried chicken yang satu 
dengan yang lainya menggunakan bahan baku dan pengolahan yang sama serta menghasilkan produk yang sama. Dengan pemberian nama terhadap suatu produk yang dihasilkan, pelaku usaha mikro berarti telah memiliki identitas diri bagi produk yang dihasilkan dan usaha yang dijalankan sebagai pembeda dengan pelaku usaha mikro yang lain dalam jenis usaha yang sama. Dalam kaitanya dengan teknologi digitalisasi, menetapkan merek produk sangat penting karena memudahkan konsumen dalam memasukan kata kunci dalam mesin pencarian dari berbagai aplikasi online shop, market place maupun media sosial. Melalui kemudahan ini, hal ini akan berdampak baik terhadap peningkatan jumlah penjualan produk.

Analisis penetapan harga merupakan komponen yang kedua yang harus diterapkan oleh pelaku usaha mikro. Harga merupakan penjabaran dari pengembalian tingkat biaya dan keinginan keuntungan yang akan diperoleh. Dalam perkembangan bisnis yang dilakukan pelaku usaha mikro kaitanya terhadap harga, permintaan yang terjadi dalam bisnis usaha mikro masuk dalam kategori permintaan elastis, dimana perubahan harga yang terjadi akan berpengaruh signifikan terhadap volume penjualan. Elastisitas harga permintaan (price elasticity of demand) sebagai suatu konsep yang menghubungkan perubahan kuantitas pembelian/ permintaan optimal atas suatu komoditi dengan perubahan harga relatifnya ( Miller dan Meiner, 2000 :111). Berkaitan dengan hal ini, melihat segmentasi kosumen dalam kegiatan pelaku usaha mikro dapat dilihat berdasarkan harga produk yang dihasilkan oleh pelaku usaha mikro yang identik dengan harga murah, kenaikan harga lima ratus rupiah dapat berpengaruh sangat signifikan terhadap volume penjulan. Kenaikan harga yang dilakukan oleh pelaku usaha mikro tentunya ada sebab yang melatarbelakaninya, salah satunya yaitu kenaikan harga terhadap bahan baku suatu produk. Terdapat 2 pilihan yang harus diambil oleh pelaku usaha mikro ketika menghadapi situasi kenaikan harga terhadap bahan baku yang berdampak akan berubahnya harga jual pada sebuah produk, pilihan pertama yaitu dengan mengurangi jumlah keuntungan yang akan diperoleh sehingga harga jual akan tetap sama dan pilihan yang kedua yaitu dengan tetap dengan keuntungan yang diperoleh sehingga menaikan harga jual namun beresiko terhadap 
berkurangnya volume penjualan produk. Dalam kaitanya dengan teknologi digitalisasi, penetapan harga suatu produk akan dapat dengan mudah dibandingkan dengan harga produk sejenis yang lain oleh konsumen secara cepat ketika konsumen menggunakan aplikasi online shop maupun market place. Harga yang kompetitif perlu diperhitungkan dengan baik oleh pelaku usaha mikro melalui efesiensi faktor produksi karena konsumen cenderung lebih memilih harga yang murah dan terjangkau.

Hal mendasar yang harus tetap dipertahankan oleh pelaku usaha mikro dan merupakan ciri khas/krakteristik yang dimiliki oleh pelaku usaha mikro dalam era Revolusi Industri 4.0 adalah harga jual yang murah, harga jual ini dapat dijangkau oleh segmentasi pasar menengah kebawah. Hal ini penting karena mayoritas konsumen dari kegiatan usaha mikro adalah konsumen menengah kebawah. Dalam pandangan konsumen menengah ke bawah bahwa produk dianggap memiliki kualitas jika dijual dengan harga murah. Hal ini karena harga murah memiliki kesesuaian dengan tingkat pendapatan yang dimiliki oleh mayoritas konsumen usaha mikro. Kesesuaian tingkat harga dan kemampuan konsumen inilah yang menjadi dasar sebuah produk dikatakan berkualitas. Senada dengan hal ini, harga murah adalah sumber kepuasan yanng penting karena mereka akan mendapatkan value of money yang tinggi (philip kotler, 2002:54).

Komponen yang ketiga merupakan komponen yang penting dalam pengembangan kegiatan usaha bagi pelaku usaha mikro di era Revolusi Industri 4.0 yaitu distribusi. Berkaitan dengan hal ini terdapat 2 istilah yang membedakan bagaimana mekanisme distribusi ini dilakukan yaitu tempat pasar dan ruang pasar. Tempat pasar merupakan lokasi fisik di mana pemasok dan pelanggan bertemu untuk melakukan bisnis baik berupa modern market seperti mall maupun berupa traditional market seperti pasar trasional. Sedangkan ruang pasar merupakan lokasi maya yang dimungkinkan oleh adanya sambungan telepon dan internet di mana pelanggan dan pemasok melakukan bisnis secara elektronik seperti online shop maupun market place. Pelaku usaha mikro harus dapat membiasakan diri untuk dapat meninggalkan zona nyamanya yang dilakukan melalui tempat pasar, yaitu dengan mulai menggunakan ruang pasar dalam menjalankan kegiatan usahanya 
agar memperoleh lebih banyak konsumen. Penggunaan tempat pasar dan ruang pasar dapat dikombinasikan dalam pelaksanaan kegiatan usaha mikro. Penggunaan tempat pasar merupakan bagian dari kearifan lokal yang dapat mengedepankan keramahtamahan, komunikasi yang positive, serta kedekatan emosional dalam sebuah kegiatan usaha yang tetap penting untuk dilakukan. Kearifan lokal tetap penting dalam menjalankan kegiatan usaha mikro karena usaha mikro memiliki lokasi fisik usaha dekat dengan konsumen akhir. Kearifan lokal sebagai kepribadian, identitas kultural masyarakat, yang berupa nilai, norma, etika, kepercayaan, adat istiadat, dan aturan khusus yang diterima oleh masyarakatnya dan teruji kemampuannya sehingga dapat bertahan secara terus menerus (Sartini, 2009:28-37). kearifan lokal juga dapat dipahami sebagai usaha manusia dengan menggunakan akal budinya (kognisi) untuk bertindak dan bersikap terhadap sesuatu, objek, atau peristiwa yang terjadi dalam ruang tertentu (Ridwan, 2007:2738). Senada dengan hal itu menurut Geriya, Kearifan Lokal berorientasi pada (1) keseimbangan dan harmoni manusia, alam dan budaya: (2) kelestarian dan keragaman alam dan kultur ; (3) konservasi sumber daya alam dan warisan budaya ; (4) penghematan sumber daya alam yang bernilai ekonomis ; (5)moralitas dan spiritualitas (Permana 2010:6).

Dengan berkembanganya teknologi digitalisasi yang merupakan sebuah peluang besar bagi para pelaku usaha mikro untuk dapat meningkatkan volume penjualan serta menjadikan kegiatan usahanya lebih dikenal secara luas serta dapat mengembangkan usahanya lebih besar lagi ke level usaha kecil maupun menengah (Lilik Handajani, Lalu Muhammad Akram Furkan, dan Ahmad Rifa'i, 2019). Dalam kaitanya dengan teknologi digitalisasi, pentingnya pertimbangan yang dilakukan dalam memilih ruang pasar yang tepat bagi pelaku usaha mikro dalam distribusi barang adalah ruang pasar yang memiliki biaya paling murah tetapi memiliki target pasar yang luas, menurut peneliti ruang pasar yang cocok digunakan oleh pelaku usaha mikro adalah dengan menggunakan media sosial sepertifacebook, instagram, maupun twitter. Menurut data berdasarkan hasil riset We Are Sosial Hot Suite yang dirilis Januari 2019 pengguna media sosial di Indonesia mencapai 150 juta atau sebesar 56\% dari total populasi. Sementara 
pengguna media sosial mobile (gadget) mencapai 130 juta atau sekitar $48 \%$ dari populasi.

Kemudahan akses yang di dapat dari teknologi digitalisasi dapat dimanfaatkan betul oleh pelaku usaha mikro untuk dapat memperoleh konsumen baru dengan meyakinkan konsumen potensial melalui edukasi konsumen yang merupakan komponen keempat dalam penerapan strategi pemasaran. Edukasi konsumen ini dimaksudkan agar pelanggan dapat melalui 3 tahap perkembangan terhadap suatu produk yang bertujuan agar konsumen membeli produk yang dipasarkan, 3 tahap perkembangan tersebut yaitu kognitif (pengetahuan), afektif (sikap), dan psikomotor (perilaku). Pada tahap kongintif, informasi atau pesan yang disampaikan oleh pelaku usaha dengan menggunakan media sosial harus dibuat semenarik mungkin melalui gambar yang bagus, tata bahasa yang santun serta deskripsi produk yang jelas. Hal ini dimaksudkan agar konsumen memiliki ketertarikan untuk mengetahui informasi atau pesan yang disampaikan. Ketertarikan untuk mengetahui ini menjadi pintu awal informasi masuk dan menjadi pengetahuan bagi konsumen.

Melalui pengetahuan yang diperoleh tentang suatu produk, akan menjadikan pelanggan memiliki perubahan sikap (afektif) terhadap produk tersebut dengan timbul perasaan ingin mencoba ataupun ingin membeli. Dalam perkembangan afektif ini peranan harga menjadi pertimbangan utama bagi konsumen untuk membeli atau tidak membeli bagi konsumen potensial, sedangkan bagi pelanggan yang loyal bukan hanya harga tetapi juga kualitas produk dan pengalaman yang dirasakan menjadi pertimbangan untuk membeli atau tidak membeli. Perilaku nyata dalam tindakan membeli dan tidak membeli merupakan tahap perkembangan psikomotor. Edukasi konsumen merupakan hal penting yang perlu dipahami dan diterapkan oleh pelaku usaha mikro agar usahanya dapat berkembang secara berkelanjutan.

Berkaitan dengan hal tersebut, penggunaan media sosial memiliki banyak keunggulan dalam penerapan strategi pemasaran bagi pelaku usaha mikro. Hal pertama yang menjadi pertimbangan adalah tentang rendahnya biaya yang dikeluarkan dalam mempromosikan produk, pelaku usaha mikro hanya membutuhkan akses internet untuk dapat mengoprasikan akun media sosial 
miliknya. Media sosial juga memberikan respon yang cepat dari konsumen yang tertarik untuk membeli bagi produk yang dipasarkan. Selain itu juga, kemudahan akses yang tersedia 24 jam serta banyaknya pengguna media sosial menjadikan media sosial sebagai sarana promosi produk yang menjanjikan. Namun dari keunggulan ini, media sosial memiliki kekurangan. Diantara kekurangannya yaitu media sosial rentan terjadi penipuan baik dari sisi konsumen dengan pembayaran yang bermasalah maupun dari pelaku usaha mikro sendiri yang tidak konsisten antara produk yang pasarkan dengan produk yang sesungguhnya dijual seperti menyampaikan informasi produk yang berlebihan atau tidak sesuai antara photo atau deskripsi produk dengan produk aslinya.

Perkembangan ilmu pengetahuan dan teknologi telah mendorong kemajuan di semua bidang kehidupan, termasuk kemajuan dalam bidang teknologi informasi (Siti Khodijah dan Yeti Nurizzati, 2018). Seiring arus globalisasi tuntutan kebutuhan informasi yang cepat membuat peranan teknologi komunikasi menjadi sangat penting (Khavid Khalwani dan Yeti Nurizzati, 2019). Senada dengan hal itu, di era revolusi industri 4.0 perubahan selera konsumen dan kecepatan informasi pun tidak dapat dihindarkan (Hanindyalaila Pienrasmi dan Dora Rinova, 2019). Tantangan ini harus dapat di antisipasi dengan baik oleh pelaku usaha mikro melalui inovasi produk dan peningkatan kompetensi yang dimiliki. Perubahan selera merupakan hal yang tidak dapat dihindarkan dalam perkembangan era teknologi digitalisasi saat ini, hal ini disebabkan karena banyakdan mudahnya informasi yang didapatkan oleh konsumen. Keterbaruan inovasi produk dan rasa ingin mencoba hal-hal baru bagi konsumen menjadi rangsangan tersendiri bagi konsumen dalam memuaskan kebutuhanya. Menyikapi hal ini, pelaku usaha mikro belum menyadari bahwa keterbaruan inovasi produk merupakan salah satu langkah dalam menyikapi selera konsumen yang sangat cepat berubah. Pelaku usaha mikro masih memiliki anggapan yang sederhana berkaitan dengan hal ini. Salah satu penyebabnya adalah pelaku usaha mikro tidak memiliki kepercayaan diri untuk mencoba hal-hal baru terhadap produk yang dihasilkan. Ada kekhawatiran bahwa produknya tidak akan laku yang mengakibatkan masalah terhadap perputaran modal yang digunakan. 
Berkaitan dengan hal tersebut, pelaku usaha mikro dapat menerapkan sistem sales promotion dalam memperkenalkan produk. Promosi penjualan adalah setiap bentuk komunikasi yang digunakan oleh perusahaan (pemasar) untuk memberitahukan (informasi), membujuk, atau mengingatkan orang mengenai produk, jasa, bayangan (image), gagasan (ide) atau keterlibatan perusahaan dan masyarakat dengan maksud agar dapat menerima dan melakukan perbuatan sebagaimana yang dikehendaki oleh perusahaan (Sigit, 2002:53). Disamping itu, promosi penjualan adalah insentif jangka pendek untuk mendorong pembeli dari suatu produk atau jasa (Kotler dan Amstrong (2001:173). Dengan menggunakan sales promotion ini pelaku usaha mikro dapat meningkatkan volume penjulan produk serta memperkenalkan produk baru sebagai tawaran untuk menarik minat konsumen. Pelaku usaha mikro dapat mecoba dengan skema buy 3 get 1 new poduct yang artinya bahwa dengan membeli 3 produk yang lama telah dijual, pelanggan secara gratis mendapatkan 1 produk baru. Melalu hal ini, pelaku usaha mikro juga dapat memberikan layanan berkelanjutan dalam kemasan produk baru, pelaku usaha mikro dapat mencantumkan akun media sosial yang dapat konsumen akses untuk memberikan tanggapan atau feed back terhadap kualitas produk baru yang di jual. Melalui mekanisme ini pelaku usaha mikro dapat melakukan perbaikanperbaikan mendasar terhadap produk baru yang di jual sebagai bentuk penyempurnaan produk. Berkaitan dengan hal tersebut, peranan teknologi digitalisasi berkaitan informasi terhadap tanggapan kualitas produk dari konsumen dapat sangat cepat di terima oleh pelaku usaha mikro melalui akun media sosial yang dimiliki. Kecepatan informasi ini menjadi sangat penting dalam sebuah kegiatan usaha karena semakin mempercepat proses penyempurnaan produk baru yang akan dijual secara ekonomis.

Dalam perkembangan teknologi digitalisasi, konsumen mengharapkan pelayanan yang cepat dan mudah terhadap apa yang mereka butuhkan. Konsumen akan memiliki tingkat kepuasan jika mereka tidak harus pergi keluar rumah namun produk dapat dikirimkan langsung kerumah. Terdapat dua pilihan bagi pelaku usaha mikro menanggapi hal ini, pertama adalah menyediakan informasi pemesanan yang dikelola mandiri yang dapat di informasikan melalui media sosial maupun dilokasi 
tempat pelaku usaha mikro melakukan kegiatan usaha dengan resiko menambah jumlah tenaga keja untuk melakukan kegiatan pengiriman produk. Kedua, pelaku usaha mikro dapat bekerja sama dengan penyedia layanan start up jasa transportasi secara daring seperti halnya gojek dengan layanan produknya go food maupun grab dengan produk layanannya grab food untuk membantu kemudahan pelaku usaha mikro dalam menjual produknya dengan mekanisme bagi hasil yang jelas.

Dalam sistem pembayaran, pelaku usaha mikro dapat mulai menggunakan uang elektronik sebagai salah satu alternative pembayaran. Walaupun ini akan terasa lebih sulit bagi pelaku usaha mikro, namun dengan perkembangan teknologi digitalisasi hal ini tidak dapat dikesampingkan. Ada ketakutan dibenak pelaku usaha mikro ketika bertransaksi menggunakan uang elektronik, kurang pahamnya dalam menggoperasikan alat dan sistem dalam pembayaran menggunakan uang elektronik menjadi salah satu penyebabnya. Selain itu juga ada rasa khawatir takut salah serta takut uangnya hilang karena tidak terbiasa menggunakan uang eleketronik serta kebiasaan dalam hal pembayaran yang merasa lebih nyaman jika uang langsung ada digenggaman tangannya.

Selain itu, kualitas sebuah produk menjadi hal mutlak yang harus dipahami oleh pelaku usaha mikro dalam menjamin kualitas dari produk yang dihasilkan dalam persaingan di era Revolusi Industri 4.0. Semakin tinggi tingkat kualitas produk maka semakin tinggi pula tingkat kepuasan konsumen yang dihasilkan (Kotler \& Keller, 2009:144). Produk yang berkualitas tinggi merupakan produk yang mampu unggul dalam bersaing untuk memenuhi kebutuhan konsumen (Wood, 2009: 124). Disamping itu juga, kualitas produk merupakan evaluasi yang dilakukan oleh konsumen atas kebaikan kinerja barang atau jasa (Mowen dan Minor, 2002: 90),.

Kualitas yang dimaksud harus dapat berkembang secara bekelanjutan dan konsisten. Kualitas merupakan sebuah isu bisnis, bukan merupakan sebuah isu tekhnis. hal ini berarti, kualitas merupakan sesuatu yang terdapat dalam setiap unsur kegiatan usaha mulai dari pengadaan bahan baku, proses produksi, promosi produk, penetapan harga, pelayanan, dan tindak lanjut pasca penjualan. sedangkan Isu tekhnis dalam hal ini adalah kualitas merupakan unsur yang diperlukan dalam 
mendukung kelancaran kegiatan produksi saja. Kualitas harus mampu direalisasikan secara menyuluruh dalam konsep bisnis, hal ini dibutuhkan pelaku usaha mikro dalam menghadapi persaingan usaha di era Revolusi Industri 4.0 sekarang ini.

Keberlangsungan sebuah kegiatan usaha tergantung dari kualitas yang dihasilkan. Menurut Domingo, salah satu bentuk identitas kualitas yaitu kualitas adalah tenaga penjual yang pendiam, artinya bahwa dengan mempertahankan ataupun meningkatkan kualitas tehadap produk, maka secara langsung kepercayaan konsumen atas kebermanfaatan produk akan terjaga yang berdampak terhadap volume penjualan kegiatan usaha mikro terus stabil serta dapat meningkatkan volume penjualanya dari waktu ke waktu (Soegito, AT, 2011:37). Perlu diketahui bahwa kualitas di tentukan oleh pelanggan, hanya pelanggan yang mempunyai hak untuk menentukan ataupun menilai suatu produk itu berkualitas maupun tidak. Jika pelaku usaha mengatakan bahwa produknya berkualitas tanpa ada bukti ulasan konsumen yang valid, hal ini disebut dengan klaim kualitas sepihak bahkan dapat disebut dengan berita bohong (fake news).

Kualitas memiliki pengaruh yang sangat besar terhadap keberlangsungan kegiatan usaha mikro, tanpa kualitas yang baik modal yang sudah dikeluarkan akan sulit mencapai tingkat pengembalian produksi maupaun tingkat pengembalian investasi. Penjaminan terhadap kualitas produk menjadi sebuah hal yang diperhatikan oleh pelaku usaha mikro. Hal ini karena, ketercapaian tingkat kepuasan konsumen terdapat dalam kualitas. Melalui kualitas ini, konsumen memiliki dasar dalam melakukan tindakan pembelian. Dengan demikian, tindakan pembelian yang dilakukan konsumen merubah harga yang telah ditentukan menjadi sebuah pendapatan sebagai bentuk tingkat pengembalian produksi dan keuntungan yang diharapkan. Dalam bauran pemasaran, harga merupakan satu-satunya unsur yang mengandung pendapatan. Maka dari itu, kosep kualitas berhubungan erat terhadap modal dan keuntungan yang akan diperoleh pelaku usaha mikro.

Dalam perkembangan era teknologi digitalisasi ini, kecepatan informasi dan layanan merupakan hal mendasar yang harus dapat dipenuhi oleh pelaku usaha mikro. Disamping itu, kecepatan informasi dan layanan harus memiliki standar 
kualitas yang baik. Standar kualitas ini merupakan tolak ukur yang diyakini dan dilaksanakan dengan komitmen sebagai sebuah filosofi dalam berbisnis bagi pelaku usaha mikro. Standar kualitas ini harus menjiwai strategi pemasaran mulai dari internal marketing, eksternal marketing maupun interaktive marketing yang juga dikombinasikan dengan teknologi digitalisasi. Teknologi akan membawa pengaruh dalam setiap interaksi perusahaan, pelanggan dan karyawan yang berdampak pada efektivitas pemasaran (Parasuraman, 2000:307-320). Dalam internal marketing, pelaku usaha mikro dapat mengkonsep janji-janji strategis dalam upaya meningkatkan pelayanan dan penjualan produk berkaitan dengan hal-hal yang akan disampaikan ke konsumen, seperti halnya dengan meberikan sebuah jaminan terhadap rasa, jaminan kecepatan pelayanan atau jaminan kebersihan atau kehalalan dari suatu produk yang dijual.

Dalam eksternal marketing, pelaku usaha mikro dapat menggunakan strategi promosi yang terjangkau baik dari sisi biaya maupun dari sisi kemampuan pelaku usaha mikro mengakomodasi strategi promosi yang digunakan. Dalam hal ini pelaku usaha mikro dapat menggunakan media internet dengan promosi melalui media sosial dengan pertimbangan biaya yang murah dan mudah di aplikasikan serta segmentasi sasaran konsumen yang cukup luas. Dalam mengaplikasikan interaktive marketing pelaku usaha mikro dapat melakukan pelayanan yang ramah, penuh emphaty, ataupun dengan sikap yang akrab seperti halnya menanyakan nama, alamat rumah, maupun mendoakan konsumen agar selalu diberi kesehatan. Teknolgi digitalisasi yang di dukung dengan pelayanan yang berdasarkan sikap yang ramah, akrab, dan penuh emphaty yang merupakan bagian dari kearifan lokal merupakan rumusan yang sangat baik bagi pelaku usaha mikro dalam menghadapi era revolusi industri 4.0.

Pelaku usaha mikro harus memahami dengan baik bahwa konsep berbisnis bukan hanya mendapatkan laba dari kegiatan usaha yang dilakukan tetapi lebih jauh lagi yaitu memiliki kedekatan secara emosional dengan memberikan hubungan jangka panjang yang baik melalui sebuah pelayanan yang berbasiskan kearifan lokal. Perlu dipahami pula bahwa keinginan konsumen bukan hanya mendapatkan apa yang mereka butuhkan tetapi juga konsumen menginginkan rasa dihargai 
selama proses transaksi pembelian yang dilakukan. Setelah dipahami, konsep ini harus mampu di aplikasikan dan di hayati dengan penuh kesadaran agar tidak menjadi sebuah keterpaksaan tetapi dapat menjadi sebuah budaya berbisnis yang baik bagi pelaku usaha mikro.

\section{KESIMPULAN}

Teknologi digitalisasi sebagai sebuah ciri dari era Revolusi Industri 4.0 merupakan salah satu bentuk penerapan pelayanan self service yang berarti bahwa ketercapaian kepuasan pengguna tergantung dari kemampuan pengguna itu sendiri atau dengan kata lain pengguna berkontribusi terhadap kepuasan layanan yang akan diperoleh bagi kepuasan dirinya sendiri.

Terdapat 4 komponen utama dalam penerapan strategi pemasaran yaitu spesifikasi produk dengan merek, analisis penetapan harga, distribusi yang digunakan, dan mekanisme mengenalkan produk dengan melakukan edukasi terhadap konsumen. komponen yang pertama yaitu spesifikasi produk dengan merek tertentu, hal ini penting karena suatu produk harus memiliki identitas sebagai pembeda terhadap produk yang dihasilkan oleh pesaing. Dengan memiliki merek/nama produk yang dihasilkan, pelaku usaha mikro akan memiliki identitas terhadap produk ataupun bisnis yang dijanlankan. Hal ini akan menimbulkan ekuitas terhadap merek, dimana merek akan tertanam kuat dalam benak dan ingatan pelanggan. Kemudian, Analisis penetapan harga merupakan komponen yang kedua yang harus di terapkan oleh pelaku usaha mikro. Harga merupakan penjabaran dari pengembalian tingkat biaya dan keinginan keuntungan yang akan diperoleh. Dalam perkembangan kegiatan usaha yang dilakukan pelaku usaha mikro kaitanya terhadap harga, permintaan yang terjadi dalam bisnis usaha mikro masuk dalam kategori permintaan elastis, dimana perubahan harga yang terjadi akan berpengaruh signifikan terhadap volume penjualan.

Komponen yang ketiga merupakan komponen yang penting dalam perkembangan revolusi industri 4.0 yaitu distribusi. Berkaitan dengan hal ini terdapat 2 istilah yang membedakan bagaimana mekanisme distribusi ini dilakukan yaitu tempat pasar dan ruang pasar. Tempat pasar merupakan lokasi fisik di mana pemasok dan pelanggan bertemu untuk melakukan bisnis baik berupa modern 
market seperti mall maupun berupa traditional market seperti pasar trasional. Sedangkan ruang pasar merupakan lokasi maya yang dimungkinkan oleh adanya sambungan telepon dan internet di mana pelanggan dan pemasok melakukan bisnis secara elektronik seperti online shop. Mekanisme mengenalkan produk dengan melakukan edukasi terhadap konsumen yang merupakan komponen ke empat dimana edukasi konsumen ini dimaksudkan agar pelanggan dapat melalui tiga tahap perkembangan terhadap suatu produk yang bertujuan agar konsumen membeli produk yang dipasarkan, tiga tahap perkembangan tersebut yaitu kognitif (pengetahuan), afektif (sikap), dan psikomotor (perilaku).

Berkaitan dengan hal itu, kecepatan informasi dan layanan harus memiliki standar kualitas yang baik. Standar kualitas ini merupakan tolak ukur yang diyakini dan dilaksanakan secara konsisten dan komitmen sebagai sebuah filosofi dalam berbisnis bagi pelaku usaha mikro. Standar kualitas ini harus menjiwai strategi pemasaran mulai dari internal marketing, eksternal marketing maupun interaktive marketing. Berkembangnya teknologi digitalisasi tidak serta merta menjadikan pelaku usaha mikro meninggalkan kearifan lokal dalam perilaku berbisnis. Teknolgi digitalisasi yang di dukung dengan pelayanan yang berdasarkan sikap ramah, akrab, dan penuh emphaty yang merupakan bagian dari kearifan lokal merupakan rumusan yang sangat baik bagi pelaku usaha mikro dalam menghadapi era revolusi industri 4.0.

\section{REFERENCES}

Arikunto, S. 2013. Prosedur Penelitian (Suatu Pendekatan Praktik). Jakarta. Rineka Cipta.

A.T, Soegito. 2011 Total Quality Manajemen (TQM) Di Perguruan Tinggi. UPT UNNES Press. Semarang

Eka, Permana. 2010. Kearifan Lokal Masyarakat Baduy dalam menghadapi bencana. Jakarta. Wedatama Widya Sastra.

Fadly, Muhtad dan Wantoro, Agus. 2020. Manajemen Hubungan Pelanggan (CRM) dengan Kombinasi Media Sosial untuk Meningkatkan Penjualan. Jurnal Ekonom Bisnis. Vol. 25. No. 2, Hal. 149-158

Handajani, L., Furkan, L. M. A., dan Rifa'i, A. 2019. Penggunaan Pemasaran Digital pada Usaha Home Industry Kopi Lombok Di Desa Sigerongan 
Kabupaten Lombok Barat. Jurnal Abdi Insani. Vol. 6. No. 3, Hal. 409421

Khalwani, Khavid dan Nurizzati, Yeti. 2019. Pengaruh Penggunaan Media Komunikasi (Smartphone) Terhadap Interaksi Sosial Mahasiswa. Jurnal Edueksos. Vol. 8. No 2, Hal. 161-176.

Khodijah, Siti dan Nurizzati, Yeti. 2018. Dampak Penggunaan Teknologi Informasi dan Komunikasi Terhadap Perilaku Sosial Siswa Di MAN 2 Kuningan. Jurnal Edueksos. Vol. 7. No 1, Hal. 14-27.

Kotler, Philip. 2002. Manajemen Pemasaran 1. Milenium ed. Jakarta. PT. Prenhalindo

Kotler, P dan Amstrong, G. 2001. Prinsip-prinsip Pemasaran Jilid II Edisi ke 8. Jakarta. Erlangga

Kotler, P \& Amstrong, G. 2008. Prinsip-prinsip pemasaran edisi 12. Jakarta. Erlangga.

Kotler, P \& Amstrong, G. 2014. Principles of marketing 15Eth. New Jersey: Pearson Prentice Hall

Kotler, P., \& K.L. Keller. 2009. Manajemen Pemasaran Jilid 1, cetakan Ketigabelas. Jakarta. Erlangga.

Kurtz, D. L. 2008. Principles of contemporary Marketing. Stamford. Educational Publishing

Miller, R.L. dan Meiners E, R. 2000. Teori Mikroekonomi Intermediate, penerjemah Haris Munandar. Jakarta . PT Raja Grafindo Persada.

Mowen, J. C., \& M. Minor. 2002. Perilaku Konsumen Jilid I. Jakarta. Erlangga.

Parasuraman, A. 2000. Technology Readiness Index (TRI): Multiple Item Scale to Measure Readiness to Embrace New Technologies. Journal of Service Research, Vol. 2. No. 4, Hal 307-320

Pienrasmi, Hanindyalaila dan Rinova, Dora. 2019. Perubahan Lands Cape Komunikasi Pemasaran Di Era Digital pada Kelompok Pengrajin Batik Tulis Lampung. Jurnal Sosial dan Humanis Sains. Vol. 4. No. 1, Hal. 4355.

Prasetyo , H. dan Sutopo, W. 2018. Industri 4.0 : telaah klasifikasi aspek dan arah perkembangan riset. Jati Undip : Jurnal tekhnik Industri undip. Vol. 13. No. 1, Hal. 17-26.

Pratama, Yuga. 2019. Analisa Penentu Keputusan Pembelian Konsumen Terhadap Produk Online (Pada Masyarakat Jabodetabek) Produk Online (Pada Masyarakat Jabodetabek). Jurnal Pemasaran Kompetitif. Vol. 3. No. 1, Hal. 25 
Ridwan, N.A. 2007. Landasan Keilmuan Kearifan Lokal. Jurnal Studi Islam dan Budaya Vol.5. No. 1, Hal 27-38.

Sartini, N. W. 2009. Menggali Nilai Kearifan Lokal Budaya Jawa Lewat ungkapan (Bebasan, Saloka, dan Paribasa). Jurnal Ilmiah dan Sastra. Vol. 5. No. 1, Hal. 28-37.

Sigit, Soehardi. 2002. Pemasaran Praktis Edisi 3. Yogyakarta. BPFE

Sugiyono. 2005. Memahami Penelitian Kualitatif. Bandung: Alfabeta.

We are sosial. 2019. Data Pengguna Telepon, Internet, Media Sosial Indonesia. https://databoks.katadata.co.id/datapublish/2019/02/08/berapapengguna-media-sosial-indonesia (diakses tanggal 25 Februari 2020)

Wood, M. B. 2009. Buku Panduan Perencanaan Pemasaran, Edisi Ketiga. Jakarta. PT Indeks 